\title{
A Corpus-Based Study on the Performance of the Suggestion Speech Act by Chinese EFL Learners
}

\author{
Tongqing $\mathrm{Gu}^{1}$ \\ ${ }^{1}$ School of Foreign Languages, China West Normal University, Sichuan, China \\ Correspondence: School of Foreign Languages, China West Normal University, No. 1 Shi Da Road, Nanchong \\ 637009, Sichuan, China. E-mail: gutongqing820@gmail.com
}

Received: November 30, 2013 Accepted: January 1, 2014 Online Published: January 24, 2014

doi:10.5539/ijel.v4n1p103

URL: http://dx.doi.org/10.5539/ijel.v4n1p103

The research is financed by the Department of Education of Sichuan Province (Project No. 10SA023).

\begin{abstract}
The suggestion speech act has not been as widely studied as other speech acts such as requests and apologies, and fewer studies of suggestions have focused on Chinese EFL learners as a target group. This study, based on the spoken data of the Spoken and Written English Corpus of Chinese Learners (SWECCL) and the online Michigan Corpus of Academic Spoken English (MICASE), aims to investigate how Chinese EFL (English as a foreign language) learners make suggestions in English, through comparing the linguistic features of suggestion speech act as well as suggestion strategies used by Chinese EFL learners and native English speakers. Results show that (1) Chinese learners used significantly more modal verbs, explicit performatives and conditional structures than native English speakers, whereas native English speakers used more Wh-questions and Let's structures than Chinese learners, and (2) in terms of suggestion strategies, the Chinese EFL learners resembled native English speakers in the use of direct suggestion strategies, but the Chinese EFL learners used significantly more conventionalized indirect suggestion strategies than native English speakers.
\end{abstract}

Keywords: speech act, suggestion, pragmatic competence, corpus

\section{Introduction}

It has become widely accepted that communicative competence should be the goal of foreign/second language education. The concept of communicative competence, originated by Hymes (1972), has been reexamined and elaborated on by various scholars (Canale \& Swain, 1980; Canale, 1983; Bachman, 1990) in the past a few decades. Bachman (1990) divides communicative competence into "organizational competence," which includes both grammatical and discourse competence, and "pragmatic competence," including both sociolinguistic and "illocutionary" competence. Pragmatic competence is thus a component of communicative competence. Given the facts that pragmatic use of language in suggestions, invitations, requests and apologies is essential for language learners' communicative competence, and that the foreign/second language learners' ability to perform speech acts appropriately in a given speech event is an indication of their pragmatic competence, it is important to understand how foreign/second language learners perform such speech acts in a foreign/second language.

However, despite the richness of the cross-cultural research into many kinds of speech acts, only a handful of studies (cf. Blum-Kulka et al., 1989; Kasper \& Merete, 1991; Rose \& Kasper, 2001) have attempted to investigate the suggestion as a directive speech act. The speech act of suggestion "has not been widely examined" (Martínez-Flor, 2005, p. 168), and fewer studies have focused on Chinese EFL learners as the target group. This study, based on the spoken data of SWECCL and MICASE, compares the ways Chinese EFL learners make suggestions in English with those of native English speakers, with a focus on the linguistic features of suggestion speech act as well as the suggestion strategies used by both groups. It is hoped that the findings of this study will shed light on foreign language teaching and learning.

\section{Literature Review}

\subsection{The Suggestion Speech Act}

The concept of speech act was first coined by Austin (1962) and later developed by Searle (1969). Austin 
classifies speech acts into verdictives, exercitives, commissives, behabitives and expositives while Searle (1979, p. 13) reclassifies them into representatives, directives, commisives, expressives and declarations, in which directives are defined as "attempts by the speaker to get the hearer to do something" (qtd. in Li, 2010, p. 599). Researchers (Brown \& Levinson, 1978; Schmidt \& Richards, 1985; Banerjee \& Carrell, 1988; Marmaridou, 1990) regard a suggestion - "an utterance that the speaker intends the hearer to perceive as a directive to do something that will be to the hearer's benefit" (Banerjee \& Carrell, 1988, p. 319) as a directive speech act.

However, according to Brown and Levinson (1987), the suggestion speech act is a face-threatening act since the speaker is in some way intruding into the hearer's world by performing an act that concerns what the hearer should do. In this sense, suggestions are regarded as an imposition upon hearers by affronting their negative face (Banerjee \& Carrell, 1988). Therefore, the speaker might try to soften or mitígate the force of this speech act through the use of specific suggestion strategies in order to minimize, as far as possible, the chances of the hearer's being offended (Martínez-Flor, 2005) .

\subsection{Studies on Second Language Learners' Suggestion Speech Acts}

Banerjee and Carrell (1988) were the first scholars to conduct research on suggestions. They compared the suggestions made by 28 Chinese and Malay ESL students in English with those by 12 native speakers of American English. The data were collected through DCT (discourse completion test) and were analysed both quantitatively, in terms of frequency, directness and type of suggestion used, and qualitatively, with regard to the use of politeness strategies and redressive forms when suggesting. The findings showed a similarity by both the native speakers and non-native speakers in terms of frequency and level of directness, but a difference in the number and types of politeness strategies.

In another study, Hinkel (1997) focused on the L1 responses of NSs (native speakers) and the L2 responses given by Chinese speakers to MCs (multiple choices) and DCTs when judging the appropriateness of advice acts. When responding to the MCs, NSs selected substantially fewer options with either direct or hedged advice than the Chinese speakers, while significantly more NSs than Chinese preferred direct and hedged advice in response to DCTs. Hinkel concluded that DCTs may not be the best elicitation instrument for LI and L2 data pertaining to ambiguous and situationally constrained pragmalinguistic acts (p. 1).

Bardovi-Harlig and Hartford (1990) examined the use of suggestion speech acts by NSs and NNSs (non-native speakers) in authentic academic advising sessions to find out whether the linguistic forms employed by the two interlocutors were congruent with their respective status. By comparing the linguistic negotiation of status between NSs and NNSs, they concluded that NSs of English and NNSs were different in their pragmatic competence, since NNSs did not have the ability to employ the status-preserving strategies in accordance with their status.

Based on the previous study, Bardovi-Harlig and Hartford (1993) carried out a longitudinal study to examine the change over the course of a semester in the students' ability to develop their pragmatic competence. The subjects were 16 graduate students (6 NSs and $10 \mathrm{NNSs}$ ) and 7 native English-speaking faculty members. They found that non-native English-speaking students' pragmatic competence has improved over time. However, students did not show a better ability to employ appropriate linguistic forms of the suggesting speech act owing to the lack of appropriate input regarding suggestion formulae.

Li (2010) contrasted the syntactic forms and pragmatic strategies used by Cantonese students and Australian students in making suggestions in English (their L2). Participants were high school students who were required to perform an open role play. Results showed that these Cantonese students in their L2 employed fewer syntactic types in making suggestions than Australian students whereas pragmatically, the Cantonese students resembled Australian students in their selection of perspective, directness and politeness strategies. However, there were significant differences regarding their choice of suggestion strategies and redressive actions.

More recently, Liu and Wang (2012) conducted a case study to investigate the development of making suggestions by a Chinese doctoral student in a chemistry lab at an American university over a semester. This study used naturally occurring data recorded at the beginning and end of the semester in the chemistry lab. The results showed that the linguistic devices: imperatives, modals, and minus committers that the Chinese doctoral student used to perform suggestions did not change over the semester. However, the percentage of these forms produced by the learner changed. The results suggest clear evidence of pragmatic development, particularly in the movement from direct to indirect suggestion strategies.

The review of the literature revealed that, compared with other speech acts such as requests, there are not many studies dealing with the suggestion speech act. In addition, the above-mentioned studies focus on second 
language learners, with fewer studies to date taking foreign language contexts into account, and Chinese EFL learners are still an understudied target group. This study, therefore, primarily investigates the suggestion speech act of Chinese EFL learners by using corpus data collected from role plays in order to explore the linguistic as well as pragmatic features of the suggestion speech act made by Chinese EFL learners. The results were then compared with those of native English speakers to highlight the similarities and differences between them.

\section{Methodology}

\subsection{Research Questions}

The present study, as noted above, investigates the Chinese EFL learners' performance of the suggestion speech act with reference to that of native English speakers. Specifically, the study aims to answer the following two research questions:

a. What are the linguistic features of the suggestion speech act made by Chinese learners of English in comparison with those of native English-speaking students?

b. What are the suggestion strategies employed by the Chinese learners of English compared with those of native English-speaking students?

\subsection{Materials}

The material used in this study was SECCL (Spoken English Corpus of Chinese Learners), a sub-corpus of SWECCL, which was constructed on the basis of the spoken data of university sophomores in the National Spoken English Test for English Majors (Band 4) from 1996 to 2008 in China. The test was comprised of three tasks: Task One, the retelling of a story for three minutes; Task Two, a three-minute monologue based on a given topic; and Task Three, a four-minute role play between two test-takers. The test-takers' performances were audio-recorded in language labs, and the recordings were then transcribed by researchers. The SECCL has over one million words, and the data used in this study were the transcriptions of the third task (role playing). The sample corpus was comprised of a total of 161 files, containing 84612 words.

The reference corpus used in this study was the online MICASE, a spoken language corpus of approximately 1.8 million words focusing on contemporary university speech within the microcosm of the University of Michigan. The speakers represented in the corpus included faculty, staff, and all levels of students, and native, near-native, and non-native speakers. The online corpus search of MICASE in this study was limited to the following features so as to be compatible with that of the Chinese learners. The speech event type includes study groups and discussion sections, which are similar to the role plays in the Chinese learners' corpus; the participants are undergraduates and graduates; and the nature of the interaction is highly or mostly interative. The selected online reference corpus, which contains 84561 words, is comparable with the sample corpus of Chinese EFL learners.

\subsection{Research Instrument}

Corpus concordancer, AntConc 3.2.2, a powerful software package containing several analytical and statistic tools was used. The package provides seven tools, namely Concordance, Concordance Plot, File View, Clusters, Collocates, Word List, and Keyword List. Among these tools, the Concordance tool was mainly used in order to retrieve a specified search word or sentence in all the extracted text files. Access was also available to information about the collocation and context of the search word or structure, showing where the search word or sentence comes in each file.

\subsection{Data Collection and Data Analysis}

In order to discover the linguistic features of suggestions made by Chinese learners of English, I modified the list of linguistic structures for making suggestions generated by Jiang (2006). The modification was based on a pilot study of Chinese EFL learners' performance of suggestions in English, a careful analysis of their course materials to locate the linguistic forms used for suggesting, and a pilot search in the corpus. The linguistic forms were grouped into six categories based on their grammatical features. A list of these structures used for the concordance search is in Appendix A.

The classification of suggestion strategies in this study, with reference to Blum-Kulka et al. (1989), is mainly based on Martínez-Flor (2005). Two levels of directness were distinguished in the present study, namely direct strategies and conventionally indirect strategies, depending on their directness. Direct suggestions are those whose illocutionary force is indicated in the utterance by grammatical and lexical means such as performative verbs, suggest, advise, recommend, propose, or imperative sentences. Conventionally indirect suggestions express the illocutionary force by fixed linguistic conventions established in the English-speaking society, including specific formulae How about ..., What about ..., modals, and conditionals If I were you ..., If you ... 
(Li, 2010). The coding scheme for suggestion strategies is in Appendix B.

AntConc 3.2.2 was used to search each structure in the sample corpus to determine the individual occurrences of these expressions, as well as to eliminate those occurrences "where the structure was used in the corpus for functions other than suggestions" (Jiang, 2006, p. 41). Then the frequency of suggestion formulae and suggestion strategies employed by Chinese EFL learners and native English speakers were calculated and compared in order to explore the pragmalinguistic differences between NSs and NNSs.

\section{Results and Discussion}

In this section, the analysis focuses on the performance of the suggestion speech act by Chinese EFL learners in English, with the native English students as a reference group. The frequency of the linguistic formulae and the suggestion strategies from the two corpora was presented and compared. Chi-square tests were conducted to check whether the difference between the two groups was statistically significant.

\subsection{Linguistic Formulae Used in the Suggestion Speech Act}

Table 1. Comparison of suggestion formulae between NSs and Chinese learners

\begin{tabular}{|l|cccc|}
\hline \multirow{2}{*}{ Strucures } & Chinese learners & $\begin{array}{c}\text { Native English } \\
\text { speakers }\end{array}$ & \multicolumn{2}{c|}{ Chi-square tests } \\
\cline { 2 - 5 } & Frequency & Frequency & $\mathrm{X}^{2}$ & Sig. \\
\hline Let's & 2.2 & 22.5 & 162.5007 & .000 \\
\hline Modals \& semi-modals & 86.6 & 36.3 & 179.4794 & .000 \\
You can & 60.4 & 15.6 & 238.3261 & .000 \\
You could & 1.2 & 7.1 & 39.6544 & .000 \\
You might & 0.4 & 2.2 & 12.9826 & .000 \\
You should & 13.9 & 2.0 & 84.8754 & .000 \\
You ought to & 0.2 & 0 & 2.7713 & .095 \\
You must & 2.7 & 0 & 31.8709 & .000 \\
You have to & 3.1 & 4.7 & 3.0008 & .083 \\
You need to & 0.1 & 3.9 & 38.1302 & .000 \\
You are supposed to & 0 & 0.7 & 8.3213 & .003 \\
You'd / had better & 4.6 & 0 & 54.0419 & .000 \\
\hline Wh- questions & 4.3 & 7.9 & 8.7961 & .003 \\
How about & 1.8 & 1.5 & 0.1417 & .706 \\
What about & 1.1 & 4.7 & 21.2091 & .000 \\
Why not & 1.1 & 0.8 & 0.2494 & .617 \\
Why don't you & 0.5 & 0.8 & 0.8304 & .362 \\
\hline Conditionals & 42.9 & 23.5 & 52.6159 & .000 \\
If I were you & 2.5 & 0 & 29.0995 & .000 \\
If you & 41.4 & 23.5 & 41.9810 & .000 \\
\hline Performatives & 14.7 & 0.5 & 153.693 & .000 \\
I suggest / I suggest & 12.8 & 0.1 & 139.668 & .000 \\
I advise & 2.2 & 0.1 & 26.3281 & .000 \\
I recommend & 0 & 0.7737 & .095 \\
I propose & 0.7 & 1.3868 & .238 \\
My suggestion(s) & 2.5 & 8.3141 & .003 \\
\hline Extraposed to-clauses & 0.6 & 10.5773 & .001 \\
\hline
\end{tabular}

Note. Frequency refers to the number of occurrences per 10,000 words. 
As shown in Table 1, the Chinese EFL learners used fewer Let's ... structure than did the native English students (19 vs. 190). The difference between the two groups was statistically significant $\left(X^{2}=162.5007, p=.000\right.$ $<.001)$. According to Biber et al. (1999), Let's ... is typically used to propose a joint action taken by the speaker and the hearer. However, it can sometimes be used in making suggestions when the proposed action is clearly intended to be carried out by the hearer. Compared with bare imperatives, the use of Let's ... makes the suggestion less authoritative and more collaborative. In this study the native English students used this structure much more frequently than the Chinese learners of English probably because, in study groups and discussion sections, they felt that students are supposed to be more cooperative and less authoritative. The Chinese learners, on the other hand, may have learned this structure solely as a joint action taken by both the speaker and hearer rather than as a linguistic formula to make suggestions, and thus did not use this structure as frequently as did the native English students.

Both the Chinese learners and native English students made frequent use of modals or semi-modals in making suggestions although Chinese learners used far more modals than native English students. The chi-square test indicated that there was a statistically significant difference between the two groups $\left(\mathrm{X}^{2}=179.4794, p=.000\right.$ $<.001)$. As shown in Table 1, compared with the native English-speaking students, the Chinese learners tended to overuse such obligation modals as should, must, the probability modal can and the semi-modal had better, but to underuse modals like need, might and could. Chi-square tests indicated that there were statistically significant differences in their use between Chinese learners and the native English speakers $(p<.001)$. Celce-Murcia et al. (1999) ordered modals based on the speaker's degree of authority or the urgency of the advice. The degree of a speaker's authority or urgency of the message decreases in must $>$ should/ought to $>$ mght/could. The corpus data in this study were university students' conversations on campus; thus factors like authority and ugency were not crucial in their conversations. The Chinese learners' overuse of obligation modals like should, and must and their underuse of less imposing modals like might, and could indicated their failure to recognize the degree of forcefulness of modal verbs and their insensitivity to register differences.

Table 1 also shows that you can is the most frequently used linguistic form by both Chinese learners and native English students in making suggestions. This result echoes the finding of Rintell (1981) that at the syntactic level, the most frequent linguistic form in making suggestions is "you can." One possible reason for Chinese learners' frequent use of this structure is that can is among the first modal verbs they study in their English class and therefore the most frequently used by Chinese teachers and learners. Noting the fact that the majority of English learners in China are not fully competent English users, they are apt to constantly resort to more familiar linguistic forms while avoiding less familiar ones because using simple and familiar structures makes them feel safe. As Li (2010, p. 613) argues such use may "relate to students' language competence, as well as their confidence in their own and their partners' language competence."

As for Wh-questions, the Chinese learners in this study resembled native English speakers in using this structure. The result of chi-square test showed that the difference was not significant between the two groups $\left(\mathrm{X}^{2}=8.7961\right.$, $p=.003>.001)$. According to Jiang $(2006$, p. 49$)$, the Wh-questions "seem to have acquired idiomatic status for indirect suggestions." Structures such as How about/What about ... /Why not ... /Why don't you ... have become conventionalized forms for making suggestions. The fact that in this study the Chinese learners of English used this conventionalized linguistic formula for suggestions indicates that they were familiar with the formulaic use of these questions - no doubt the result of their textbooks and teaching, which advocate the formulaic use of these questions for making suggestions. However, as shown in Table 1, the frequency of these structures was not very high in the native English corpus; thus their use should not be overemphasized.

The Chinese learners in the present study used more conditional structures than native English students in making suggestions. The chi-square test indicated that there was a statistically significant difference between the two groups $\left(\mathrm{X}^{2}=52.6159, p=.000<.001\right)$. There was significant difference in the use of the strucuture If I were you, which the native English students didn't use at all and if you $(\mathrm{p}<.001)$. Conditionals are often considered an indirect, thus more polite way of making suggestions. A possible explanation for the frequent use of conditionals by Chinese EFL learners is the importance to them of solidarity and the maintenance of harmony in their interpersonal communications. Since suggestion acts in Chinese are regarded as acts of solidarity (Martinez-Flor, 2005), Chinese learners are inclined to be indirect and polite when giving suggestions, and Li (2010) suggests the same in his study. The conditional structure, which is highlighted in grammar teaching, is readily used by Chinese EFL learners.

Regarding the use of performatives, Chinese EFL learners in the study used far more explicit performative than native Englsih students. The chi-square test indicated that there was a statistically significant difference between the two groups $\left(\mathrm{X}^{2}=153.6930, p=.000<.001\right)$. Li $(2010)$ also reports that Cantonese learners tended to use 
more explicit and overt syntactic forms when making suggestions. According to Jiang (2006, p. 45), performative verbs like suggest and advise and their corresponding nouns "are used in suggestions more frequently from the higher-status to the lower-status interlocutor on more serious topics, or things the speaker strongly believes the hearer should do". Li (2010) attributes Chinese learners' performance to their inclination to be explicit in meaning and reluctance to be misinterpreted. It is assumed that "their lack of competence in their English lends them to the preference of overt syntactic forms" (p. 611). In addition, such pragmalinguistic mismatch may be teaching-induced since Chinese learners' reliance on the explicit performatives might be a sign of their incomplete knowledge of the relation between linguistic forms and their illocutionary forces.

\subsection{The Results of Suggestion Strategies Used in the Suggestion Speech Act}

Two suggestion strategies were identified in this study. The occurrence and frequency of each strategy by the Chinese learners and the native English students are shown in Table 2.

Table 2. Suggestion strategies used by Chinese EFL learners and native English speakers

\begin{tabular}{|c|cccc|}
\hline \multirow{2}{*}{$\begin{array}{l}\text { Suggestion } \\
\text { strategies }\end{array}$} & Chinese EFL learners & Native English students & \multicolumn{2}{c|}{ Chi-square tests } \\
\cline { 2 - 5 } & Frequency & Frequency & $X^{2}$ & Sig. \\
\hline Direct & 18.0 & 22.9 & 5.1362 & .023 \\
\hline Conventionally indirect & 134.9 & 67.8 & 191.4924 & .000 \\
\hline
\end{tabular}

According to Table 2, both the Chinese EFL learners and native English students used conventionally indirect suggestion strategies very frequently (more frequently than direct strategies) although the Chinese learners preferred this strategy more than native English students. The chi-square test indicated that there was a statistically significant difference between the two groups $\left(\mathrm{X}^{2}=191.4924, p=.000<.001\right)$. This can be explained by Li's (2010, p. 611) observation that "language learners seemed to be more comfortable in those overt and conventionalized choices, avoiding the possibility of being misinterpreted or overlooked."

As for the direct suggestion strategy, the Chinese EFL learners' and native English students' usage was similar in frequency although the native English students used slightly more direcet suggestion strategies. The chi-square test indicated that there was no statistically significant difference between the two groups $\left(\mathrm{X}^{2}=\right.$ $5.1362, p=.023>.001)$. The result conforms to that of Banerjee and Carrell (1988): that NNSs resemble the NSs at the level of directness in making suggestions. In this study, the data in both Chinese learners' and native English speakers' corpora are interactions between university students who are equal in social status. Considering the nature of the interaction and the role relationships between the interlocutors, it is easy to understand the choice of direct suggestion strategies by both groups.

\section{Conclusion}

This study compared the linguistic formulae of making suggestions and the suggestion strategies of groups of Chinese EFL learners and native English students. In terms of the linguistic forms, the Chinese learners used significantly more modal verbs, explicit performatives, and conditional structures than native English speakers. However, the native English speakers used more Wh-questions and Let's structures than Chinese learners. The Chinese EFL learners' overuse and underuse of certain linguistic structures for making suggestions can be attributed to textbooks that fail to provide enough authentic and contextualized linguistic formulae for making suggestions and also to the students' relatively low linguistic competence as a result of inadequate input and sparse exposure to the target language. With regard to suggestion strategies, although the Chinese EFL learners resembled native English speakers in the frequency of their use of direct suggestion strategies, the Chinese EFL learners used significantly more conventionalized indirect suggestion strategies than native English speakers. Considering the nature of the interaction and the role relationships between the interlocutors in the data, it is reasonable for both groups to choose the direct strategies in making suggestions. As for the overwhelmingly frequent use of conventionalized indirect suggestion strategies by Chinese learners, as suggested by Li (2010), Chinese EFL learners seemed to be more comfortable in those overt and conventionalized choices in order to avoid the possilibility of being misinterpreted.

The results of the study show that Chinese EFL learners and native English speakers differ in important ways in the performance of the suggestion speech act, manifesting some divergence from native speaker norms. As a 
result of their inadequate knowledge of the linguistic forms for making suggestions, particularly the relations between linguistic forms and their illocutionary forces, their failure to recognize the degree of forcefulness of modal verbs and their insensitivity to register differences, Chinese EFL learners, to some extent, lack the ability to employ the appropriate linguistic formulae to make suggestions when interacting in English. The findings of this study clearly point to ways in which instruction and teaching material for EFL students can be communicatively strengthened.

\section{Acknowledgements}

I would like to thank my advisor Nancy Lee at EMU, and the anonymous reviewers, for their valuable comments on an earlier version of this article.

\section{References}

Austin, J. L. (1962). How to do things with words. Oxford: Oxford University Press.

Bachman, L. (1990). Fundamental considerations in language testing. Oxford: Oxford University Press.

Banerjee, J., \& Carrell, P. (1988). Tuck in your shirt, you squid: Suggestion in ESL. Language Lenaring, 38, 313-347. http://dx.doi.org/10.1111/j.1467-1770.1988.tb00416.x

Bardovi-Harlig, K., \& Hartford, B. S. (1990). Congruence in native and nonnative conversations: Status balance in the academic advising session. Language Learning, 40, 467-501. http://dx.doi.org/10.1111/j.1467-1770.1990.tb00603.x

Bardovi-Harlig, K., \& Hartford, B. S. (1993). Learning the rules of academic talk: A longitudinal study of pragmatic development. Studies in Second Language Acquisition, 15, 279-304. http://dx.doi.org/10.1017/S0272263100012122

Biber, D., Conrad, S., \& Leech, G. (1999). The Longman grammar of spoken and written English. Beijing: Foreign Language Teaching and Research Press.

Blum-Kulka, S., \& Kasper, H. J. (Eds.). (1989). Cross-cultural pragmatics: Requests and apologies. Ablex, NJ: Norwood.

Brown, P., \& Levinson, S. (1987). Politeness: Some universals in language usage. Cambridge: Cambridge University Press.

Hinkel, E. (1994). Appropriateness of advice as L2 solidarity strategy. RELC Journal, 25, 71-93. http://dx.doi.org/10.1177/003368829402500205

Hinkel, E. (1997). Appropriateness of advice: DCT and multiple choice data. Applied Linguistics, 18, 1-26. http://dx.doi.org/10.1093/applin/18.1.1

Hymes, D. H. (1972). On communicative competence. In J. B. Pride, \& J. Holmes (Eds.), Sociolinguistics: Selected Readings. Harmondsworth: Penguin.

Jiang, X. Y. (2006). Suggestions: What should ESL students know? System, 34, 36-54. http://dx.doi.org/10:1016/j.system.2005.02.003

Li, S. E. (2010). Making suggestions: A contrastive study of young Hong Kong and Australian students. Journal of Pragmatics, 42, 598-616. http://dx.doi.org/10.1016/j.pragma.2009.07.014

Liu, B. M., \& Wang, D. (2012). Learning to make suggestions in a U.S. chemistry lab: A case study of a Chinese ITA. In G. Gorsuch (Ed.), Working theories for teaching assistant development: Time-tested \& robust theories, frameworks, \& models for TA \& ITA learning (pp. 655-671). Stillwater, OK: New Forums Press.

Martínez-Flor, A. (2005). A theoretical review of the speech act of suggesting: Towards a taxonomy for its use in FLT. Revista Alicantina de Estudios Ingleses, 18, 167-187.

Martínez-Flor, A., \& Yoshinori, J. F. (2005). The effects of instruction on learners' production of appropriate and accurate suggestions. System, 33, 463-480. http://dx.doi.org/10.1016/j.system.2005.06.007

Rintell, E. (1981). Sociolinguistic variation and pragmatic ability: A look at learners. International Journal of the Sociology of Language, 27, 11-34.

Rose, K. R., \& Kasper, G. (Eds.). (2001). Pragmatics in language teaching. Cambridge: Cambridge University Press. http://dx.doi.org/10.1017/CBO9781139524797

Searle, J. (1979). Expression and meaning: Studies in the theory of speech acts. Cambridge: Cambridge University Press. http://dx.doi.org/10.1017/CBO9780511609213 
Wen, Q. F., Liang, M., \& Yan, X. (2008). Spoken and written English corpus of Chinese learners (2.0). Beijing: Foreign Language Teaching and Research Press.

\section{Appendix A}

List of structures used for concordance search (Jiang, 2006)

1) Let's ...

2) Modals and semi-modals

You have to. . .

You * have to. .. (* means with one word in-between.)

You need to. . .

You * need to. . .

You should. . .

You shouldn't. . .

You ought to. . .

You must. . .

You could. . .

You might. . .

You're supposed to. . .

You'd/had better. . .

3) Wh-questions

Why don't you ...?

Why not. .?

How about ...?

What about ...?

4) Conditionals

If I were. . .

If you. . .

5) Performatives

suggest/recommend/advise/propose

suggestion/recommendation/advice/proposal

6) Extraposed to-clauses

It might be. . . to. . .

It might not be. . . to. . .

It is $*$ to. . .

It never hurts/. . .won't hurt/. . .wouldn't hurt to. . . 


\section{Appendix B}

The coding scheme for suggestion strategies (Martínez-Flor, 2005)

\begin{tabular}{|c|c|c|}
\hline Category & Sub-category & Example \\
\hline \multirow[t]{4}{*}{ Direct } & performative verbs & I suggest/ advise/ recommend/ propose you ... \\
\hline & Noun of suggestion & My suggestion/ proposal/ recommendation ... \\
\hline & imperative sentences & Please do ... \\
\hline & & Let's ... \\
\hline \multirow[t]{14}{*}{ Conventionally indirect } & Wh-questions & Why don't you ...? \\
\hline & & How about ...? \\
\hline & & What about ...? \\
\hline & & Have you thought about ...? \\
\hline & Modals and & You can \\
\hline & semi-modals & You could \\
\hline & & You may \\
\hline & & You might \\
\hline & & You need ... \\
\hline & & You must ... \\
\hline & & You should/ ought to \\
\hline & & You had better ... \\
\hline & Conditionals & If I were you, I would ... \\
\hline & & If you ... \\
\hline
\end{tabular}

\section{Appendix C}

Task III Role-playing (Wen et al., 2008)

Student A: You will be traveling later this week and you are wondering about the advantages and safefy of flying. Recent news reports of air crashes have made you nervous and you cannot decide if it is safe to travel by airplane. You turn to your friend for advice about whether you should go by air or by train. $\mathrm{He} / \mathrm{She}$ tried to persuade you to take a flight by listing some advantages. Eventually, you refuse to accept his/her opinion and make your own decision.

Student B: One of your friends is taking a trip later this week and he/she is undecided about whether to travel by air or by train. Not knowing what to do, your friend comes to you for advice. You try to persuade your friend to take a flight in spite of reports of air crashes. Eventually, you fail to convince him/her and your friend buys a train ticket instead.

\section{Copyrights}

Copyright for this article is retained by the author(s), with first publication rights granted to the journal.

This is an open-access article distributed under the terms and conditions of the Creative Commons Attribution license (http://creativecommons.org/licenses/by/3.0/). 